\title{
As imagens de João Grilo em sua peleja argumentativa pelas veredas do Sertão: uma proposta de ensino-aprendizagem retórico-interacionista a partir da obra Auto da Compadecida
}

The images of João Grilo in his argumentative struggle through the paths of Sertão: a teaching-learning proposition based on a rhetoricalinteractionist approach of Auto da Compadecida

\section{Camila Alderete Capitani*}

ca_capitani@yahoo.com.br

https://orcid.org/0000-0003-1120-5637

\section{Resumo}

Em tempos de extremismos e polarizações, relações sociais são rompidas porque as pessoas atribuem a suas opiniões o status de verdade absoluta. Assim, não conseguem lidar com o dissenso, administrar conflitos, aceitar diferenças e respeitar o direito do outro ao questionamento. Nesse cenário, a argumentação emerge como "terceira via", pois se coaduna a uma atitude pautada pela negociação da diferença entre os sujeitos. Desenvolver, portanto, a capacidade desses sujeitos manifestarem, de modo argumentativo, suas perspectivas, discernindo de maneira crítica e analítica os posicionamentos em voga a fim de posicionarem-se e contra-argumentarem parece-nos premente no espaço escolar. O presente artigo instala-se nesse contexto e visa a responder como a análise retórico-interacionista de uma obra literária, tal qual o Auto da Compadecida, pode ser mobilizada em sala de aula para criar situações de ensino-aprendizagem problematizadoras, que possibilitem ampliar a competência argumentativa dos discentes no ensino básico.

Palavras-chave: Retórica; Argumentação; Literatura; Interação; Ensino.

Faculdade Álvares Penteado (FECAP), São Paulo, NOC Educação, Santo André, e Escola Técnica Estadual (ETEC), Ribeirão Pires, SP, Brasil. 


\begin{abstract}
In times of extremism and polarization, social relations are disrupted because people grant their opinions a status of undisputed truth. Thus, they cannot handle dissent, manage conflicts, accept diversity, and respect one's right to questioning. In such a panorama, argumentation rises as a third way, for it is consonant with an attitude oriented towards negotiating differences between subjects. Therefore, developing subjects' abilities to voice their perspectives in an argumentative fashion, discerning critically and analytically the possible positions, in order to take a stance and counterargue, seems crucial in the school environment. This article is situated in this context, and seeks to answer how a rhetoricalinteractionist analysis of a literary work, such as Auto da Compadecida, can be performed in class to create teaching-learning situations oriented towards questioning, which will help to expand students' argumentative competence in elementary school.
\end{abstract}

Keywords: Rhetoric; Argumentation; Literature; Interaction; Teaching.

\title{
Introdução
}

No âmbito de uma sociedade democrática que remete à participação cidadã, comunicar com outrem implica o recurso à argumentação. Desenvolver, pois, a capacidade de o sujeito manifestar, de modo argumentado, suas perspectivas por meio do diálogo, para posicionar-se e contra-argumentar parece-nos premente em uma sociedade que não admite a violência como método razoável à solução de problemas. Esta competência argumentativa assume uma atitude aberta nas relações com os outros, discernindo de maneira crítica os posicionamentos em voga, o universo dóxico a que se remetem os valores expostos, os enquadramentos e estratégias argumentativas empregadas na construção discursiva.

A educação escolar, que, segundo a Lei de Diretrizes e Bases da Educação Nacional $n^{0}$ 9394/96, visa a assegurar os direitos de aprendizagem e pleno desenvolvimento do educando, incluindo seu preparo para o exercício da cidadania e sua qualificação para o trabalho, constituise, portanto, em espaço plenamente adequado a tal proposição, uma vez que prevê o exercício da argumentação dentro das práticas sociodiscursivas que circulam nas diversas esferas de comunicação social.

Vista como uma atividade multidimensional, a argumentação permite desenvolver não só práticas de linguagem voltadas à leitura e à produção textual em Língua Portuguesa, mas também uma ação sociodiscursiva que visa, mediante a interação e negociação da divergência de perspectivas entre os argumentadores, a progredir para além da oposição inicial. Se considerada ainda sua dimensão cognitivo-epistêmica, implica a produção de raciocínios que englobam a ativação de pré-construídos, análise, organização e processamento de informações para construção reflexiva do conhecimento em diversas áreas.

Nesse contexto, Leitão (2011) destaca o duplo objetivo com que a argumentação pode ser trazida para a sala de aula: pode-se "ensinar a argumentar", por meio de situações de ensinoaprendizagem que favoreçam o exercício analítico, performático e interacional subjacente a

\section{LINHA DÁGUA}


essa prática discursiva; e pode-se "argumentar para ensinar", em um processo no qual a aprendizagem de conceitos e procedimentos próprios a diferentes campos de conhecimento são favorecidos pela argumentação.

O objetivo desse artigo consiste exatamente em mostrar uma via para que o docente possa construir práticas didáticas nesse sentido, produzindo tanto situações de aprendizagem argumentativa, quanto situações argumentativas de aprendizagem, isto é, tanto práticas de ensino que se propõem ao desenvolvimento de competências argumentativas pelos alunos, quanto modos de instigar, provocar, questionar, discutir e co-construir saberes por meio de uma performance argumentativa em sala de aula.

Partindo da obra literária Auto da Compadecida (2014 [1955]), construímos uma proposta didática retórico-interacionista que apresenta uma perspectiva global dos processos e procedimentos argumentativos que envolvem a construção etótica do personagem João Grilo na interação com diversos auditórios. Tendo por virtude a consistência teórica e a dimensão prática do argumentar, a proposta visa a: i) penetrar nas possibilidades oferecidas pelo texto literário a ponto de compreendê-lo como um lócus de conhecimento argumentativo que pode conduzir à participação ativa e reflexiva dos discentes na sociedade; ii) criar situações argumentativas que possibilitem ampliar, de modo articulado, a competência argumentativa dos discentes; iii) oferecer caminhos para que o docente, de maneira autônoma, possa produzir e adaptar propostas didáticas dessa natureza a sua realidade escolar, tendo em vista que para "ensinar a argumentar" e ampliar as competências argumentativas dos discentes, é necessário "argumentar para ensinar", isto é, assumir uma postura aberta à crítica, à negociação e ao diálogo, com o objetivo de que a prática seja exemplo da teoria.

Embora não haja uma bússola que garanta o sucesso absoluto dessa empreitada, porque “educar não tem precisão matemática, não se pauta por dogmas, não se guia por leis gerais e imutáveis" (FERREIRA, 2016, p. 143), isso não nos impede de problematizar os caminhos pedagógicos que trilhamos como educadores a fim de criar condições para a construção de práticas de ensino-aprendizagem, de fato, reflexivas.

\section{Uma perspectiva lítero-argumentativa para o ensino- aprendizagem}

Se, por não sei que excesso de socialismo ou de barbárie, todas as nossas disciplinas devessem ser expulsas do ensino, exceto uma é a disciplina literária que deveria ser salva, pois todas as ciências estão presentes no monumento literário.

Barthes (1997, p.16)

Com essa afirmação, proferida na aula inaugural do Colégio de França, Roland Barthes reitera a substancialidade da literatura e suas múltiplas dimensões. Por meio da palavra, "ponte

\section{LINHA D'ÁGUA}


lançada entre mim e os outros", a literatura amplia os horizontes do homem, cria e recria realidades, mostra possibilidades, constrói e reconstrói sentidos potencialmente infinitos, desperta emoções e desvela ao homem sua própria humanidade.

A literatura desenvolve em nós a quota de humanidade na medida em que nos torna mais compreensivos e abertos para a natureza, a sociedade, o semelhante. Entendo aqui por humanização o processo que confirma no homem aqueles traços que reputamos essências, como o exercício da reflexão, a aquisição do saber, a boa disposição para com o próximo, o afinamento das emoções, a capacidade de penetrar nos problemas da vida, o senso da beleza, a percepção da complexidade do mundo e dos seres, o cultivo do humor. (CANDIDO, 2011, p. 182)

Porque faz viver por meio da ficção, a literatura é, segundo Candido (2011), manifestação universal de todos os homens em todos os tempos. Não há povo que possa viver sem ela, portanto é intrínseca à sociedade, à cultura e não pode ser compreendida fora desse contexto. Deste modo, é preciso vê-la como um sistema aberto que se dilata no vasto campo da cultura universal; por isso a entenderemos de maneira mais ampla, seguindo a definição de Candido:

Chamarei de literatura da maneira mais ampla possível, todas as criações de toque poético, ficcional ou dramático em todos os níveis de uma sociedade, em todos os tipos de cultura, desde o que chamamos folclore, lenda, chiste, até as formas mais complexas e difíceis da produção escrita das grandes civilizações. (CANDIDO, 2011, p. 176)

No encontro dialógico entre duas culturas, elas não se fundem, mas se enriquecem mutuamente porque se colocam outras questões e perspectivas em discussão e, assim, constroem-se novos sentidos. A literatura é, então, uma experiência a ser realizada, é a incorporação do "outro" em "mim" sem a renúncia da minha própria identidade. No entanto, para que essa experiência se efetive, a leitura literária demanda interação entre obra e leitor. Assim, realizar essa leitura de maneira fragmentada é perder a possibilidade de revesti-la de novos sentidos, ressignificá-la e dar continuidade à criação por meio da interpretação, porque “ [...] o autor de uma obra só está presente no conjunto da obra, não se encontra em nenhum elemento destacado desse conjunto, e menos ainda no conteúdo separado desse conjunto" (BAKHTIN, 2017, p. 64-65).

Esta perspectiva embasa também a crítica de autores que discutem o ensino de literatura contemporaneamente, tais como Lajolo (1982), Zilberman (2012), Cosson (2006), Leahy-Dios (2000), Dalvi, Jover-Faleiros e Rezende (2013). Há entre eles, de modo geral, um consenso em relação ao fato de que o ensino de literatura não pode prescindir da leitura literária e não deve resumir-se à apresentação de trechos de obras em ordem cronológica a partir do viés da história da literatura ou da crítica literária como se faz atualmente nas escolas.

1 "Na realidade, toda palavra comporta duas faces. Ela é determinada tanto pelo fato de que procede de alguém, como pelo fato de que se dirige para alguém. Ela constitui justamente o produto da interação do locutor e do ouvinte. Toda palavra serve de expressão a um em relação ao outro. Através da palavra, defino-me em relação ao outro, isto é, em última análise, em relação à coletividade. A palavra é uma espécie de ponte lançada entre mim e os outros. Se ela se apoia sobre mim numa extremidade, na outra apoia-se sobre o meu interlocutor". (BAKHTIN/ VOLOCHINOV, 1988, p.113)

\section{LINHA DÁGUA}


Cosson (2006, p. 23) reivindica que “[...] se coloque como centro das práticas literárias na escola a leitura efetiva dos textos, e não as informações das disciplinas que ajudam a constituir essas leituras, tais como a crítica, a teoria ou a história da literatura". Afinal, aprender acerca do que falam os críticos não garante aos alunos conhecimento literário ou mesmo semelhante poder de crítica; pode até, ao contrário, limitar interpretações criadoras $^{2}$ e, consequentemente, empobrecer a leitura, quando a voz de autoridade do crítico é legitimada pelo professor em sala como a única interpretação plausível.

O ensino de literatura fundamentado em uma concepção humanizadora que compreende o exercício da reflexão no processo de leitura, análise e interpretação do texto literário, tal qual descrita por Candido (2011) e adotada nesse artigo, pressupõe que o leitor explore as potencialidades dessa linguagem sob a dimensão retórico-argumentativa do discurso. Este aproveitamento é possível pois esta dimensão discursiva permite observar as escolhas lexicais do autor em função do efeito desejado no texto literário, examinar a construção das personagens, perceber sob que fatos, verdades e valores o texto é concebido e esquadrinhar sua estrutura técnico-argumentativa para elucidar o efeito prático, efetivo de sua presença para além do texto.

A obra Auto da Compadecida é repleta de elementos retórico-argumentativos que conferem vivacidade ao texto. É por meio da interação argumentativa entre os personagens que o autor Ariano Suassuna (1927 - 2014) dá voz aos desvalidos, constrói-os como hábeis oradores, inverte as imagens pré-concebidas, os estereótipos, tece críticas à sociedade e leva o leitor a questionar a doxa, o conjunto de crenças e opiniões comuns, que orienta seus passos e sobre a qual estão também firmados seus valores.

João Grilo, personagem central da obra, junto a seu duplo Chicó, torna-se porta voz dessa coletividade marginal, pois vence os adversários e toda sorte de infortúnios por meio das palavras, do discurso, do lógos. Ao problematizar situações de conflito, discerne os meios de persuasão pertinentes a cada auditório e adapta-se a ele, enquadrando o assunto em questão a partir de determinada perspectiva para, enfim, influenciar-lhe o comportamento, a ação. Por meio das provas de persuasão próprias da arte retórica, constrói-se como orador/ argumentador perante um auditório heterogêneo e passa de "amarelinho safado", no primeiro ato, a porta voz do grupo, símbolo da esperança, no terceiro. Essa transformação etótica ${ }^{3}$ deve-se à sua competência argumentativa que se revela ao longo das cenas teatrais. Esse conjunto de competências que abrangem, simultaneamente, a capacidade de dialogar, interagir, pensar criticamente, optar e comprometer-se é essencial à construção de sua credibilidade como orador.

2 Entendemos "interpretação criadora" tal qual Bakhtin (2017, p. 35-36) a conceitua: “[...] a interpretação completa o texto: ela é ativa e criadora. A interpretação criadora continua a criação, multiplica a riqueza artística da humanidade. O intérprete não pode excluir a possibilidade de mudança e até de renúncia aos pontos de vista e posições já prontos".

3 Empregamos o termo "etótica" para referirmo-nos à locução adjetiva "de éthos".

\section{LINHA DÁGUA}


Ler essa obra sob o viés retórico-interacionista, observando como se constituem tais competências no personagem, permite compreender de modo mais aprofundado o processo de construção do discurso, pois as escolhas no plano da expressão, a elocutio, e a maneira de organizar internamente o texto, a dispositio, ultrapassam as fronteiras da língua comum na produção literária; as palavras recebem uma nova proposta de sentido, sensibilizam o ser humano porque penetram nos problemas da vida cotidiana e o fazem perceber os poderes da linguagem enquanto meio de interação social.

Ao abordar questões universais, o texto literário gera questionamentos e amplia horizontes, pois em contato com a perspectiva criada pelo autor, o leitor é incitado a posicionarse. A doxa de onde partem suas crenças e valores é paulatinamente contestada e, por meio do exercício da reflexão, assumindo uma postura crítica, interventiva e ativa, experimenta-se o poder libertador da literatura que, segundo Compagnon (2009), amplia horizontes e rompe o conformismo.

Considerada um exercício de pensamento que liberta o ser humano de maneiras convencionais de ver a vida, a literatura em sua função instrutiva é concebida como elemento de transformação social, pois a partir do contato com perspectivas plurais manifestas no texto literário, o leitor é levado a aprofundar e aprimorar o conhecimento de meios e estratégias argumentativas que o possibilita enquadrar o problemático, focalizar o assunto em questão, assumir posições, negociar sentidos e adequar as performances comunicativas a cada situação argumentativa, a cada tipo de auditório, com o intuito de promover mudanças, alterar posicionamentos e transformar realidades. Nesse sentido, o texto literário proporciona um conhecimento retórico-interacionista essencial à formação crítica e argumentativa dos discentes. Portanto, abordar os conceitos que esta arte retórica implementa, por meio da construção etótica do personagem João Grilo nessa obra, permite ao docente desenvolver todo o conjunto de competências argumentativas que nos permite coexistir uns com os outros em uma sociedade democrática.

Relacionar literatura à retórica não reduz o valor da arte literária; pelo contrário, valoriza-a, pois, a partir de uma perspectiva interdisciplinar, ultrapassamos a concepção fragmentada de conhecimento para assumir a dimensão plural do objeto literário, já ressaltada por Barthes (1977). Ao revelar os mecanismos de construção do texto, a análise retóricoargumentativa permite ao leitor questionar, discordar, criar hipóteses e observar como se constroem as múltiplas visões de mundo retratadas no texto para, enfim, posicionar-se perante a sociedade. Desenvolver essa competência crítica e criativa de análise por meio de um aprendizado interdisciplinar e problematizado que conduza à participação social ativa e reflexiva do aluno deveria ser um dos objetivos principais da Base Nacional Comum Curricular.

Esta é, entretanto, uma de nossas preocupações centrais: apresentar uma proposta didática que viabilize a leitura retórico-interacionista do texto literário para desenvolver a

\section{LINHA DÁGUA}


competência argumentativa do aluno ${ }^{4}$, tal qual conceituada por Grácio (2016). Esta deve pautarse na capacidade de leitura crítica do discurso alheio, tendo em vista a discutibilidade do assunto em questão, o caráter perspectivado de seu enquadramento, a seleção e disposição de argumentos apropriados à natureza dinâmica, interacional da situação argumentativa, com o objetivo de produzir discursos e contradiscursos argumentados que remetam a uma postura interventiva, comprometida com a gestão das diferenças necessária à coexistência e ajustada a uma sociedade democrática na qual o diálogo torna-se protagonista.

Para além de orientar as decisões pedagógicas e prescrever um conjunto de aprendizagens "essenciais" à formação do aluno por meio de um viés mecanicista, tecnicista e conteudista que visa à homogeneização a partir do desenvolvimento de competências consoantes à BNCC, oferecemos, neste artigo, "caminhos" para que o professor, de posse de sua autonomia, tenha condições de produzir conhecimentos ${ }^{5}$ para além de transmiti-los.

\section{A construção de um viés retórico-interacionista: reflexões teóricas}

A argumentação é um fenômeno vivo, social, pois é no domínio da controvérsia, do conflito, da polêmica, da plurivocidade e plurissignificação que ela se concretiza dentro das mais diversas situações de comunicação. Para dirimir conflitos, negociar posicionamentos, neutralizar tensões e chegar a um consenso interagimos por meio da palavra, utilizamos o lógos, o discurso.

Assim, a produção de qualquer manifestação comunicativa é uma construção retórica, visto que estamos a todo tempo construindo dialogicamente sentidos a partir dos valores e das opiniões que compartilhamos, por meio da doxa. Comunicar-se com o outro implica estar disposto a ouvir pontos de vista, interagir de modo crítico e respeitoso, observando que não se trata de uma imposição de perspectivas, nem de qualquer autoritarismo, mas da liberdade de pensar, de se expressar e de refutar o discurso do outro; a argumentação convida, enfim, a uma situação democrática e está a serviço dela, numa relação bidirecional na qual o "embate" não é físico, se constitui por meio da palavra.

4 A partir das concepções de competência e capacidades argumentativas descritas por Grácio (2016) e Azevedo (2013), consideramos capacidade a habilidade, a disposição adquirida para realizar uma atividade a partir de conhecimentos específicos e saberes de experiências; e competência, o conjunto de capacidades discursivas articuladas para agir de modo eficaz sobre o outro em situações argumentativas diversas.

5 Cabe ressaltar que na tese Articulações entre o ensino-aprendizagem de Argumentação e de Literatura: caminhos retórico-interacionistas a partir do Auto da Compadecida, (CAPITANI, 2021), da qual esse artigo é fruto, exploramos de modo mais extenso todo o arcabouço teórico que orienta os estudos retóricointeracionistas e analisamos de modo minucioso o texto literário presumindo que haja interesse, por parte do docente, em abordar a obra a partir de perspectivas não contempladas em nossa proposta didática. Enfatizamos, contudo, que esta é uma perspectiva sobre a obra, e, portanto, o docente pode desenvolver semelhante trabalho pautado em outros recortes e obras literárias.

\section{LINHA D'ÁGUA}


Nesse contexto de embate se deu sua origem por volta do século V na Sicília grega, em Siracusa, quando, após a expulsão dos tiranos Gelon e Hieron, os cidadãos deram início a processos de reintegração de posse das terras usurpadas perante um júri. Em âmbito de polêmica, a partir desse caráter prático, a retórica fortaleceu-se. Suas bases teóricas começaram a ser desenvolvidas na Grécia Antiga e foram, ao longo de séculos, sendo retomadas e aperfeiçoadas pelos demais teóricos.

Aristóteles, no livro I da obra Retórica, lança as primeiras definições gerais acerca das relações entre retórica e técnica. Ao definir aquela como "[...] a capacidade de descobrir o que é adequado a cada caso com o fim de persuadir" (ARISTÓTELES, 2012, p. 11), atribui especial importância à arte de persuadir, de agir sobre o outro, mas não a desvincula do método, tanto que distingue duas categorias formais de persuasão: provas inartísticas e artísticas:

Das provas de persuasão, umas são próprias da arte retórica e outras não. Chamo provas inartísticas a todas que não são produzidas por nós, já existem antes: provas como testemunhos, confissões sob tortura, documentos escritos e outras semelhantes; e provas artísticas, todas as que se podem preparar pelo método e por nós próprios. De sorte que é necessário utilizar as primeiras, mas inventar as segundas (ARISTÓTELES, 2012, p. 13).

Por isso, sistematizará as provas de persuasão que possibilitarão, aliadas a outros meios descritos por ele nos livros II e III, atingir o efeito desejado. Desse modo, explica que "[...] as provas de persuasão fornecidas pelo discurso são de três espécies: umas residem no caráter moral do orador; outras, no modo como se dispõe o ouvinte; e outras, no próprio discurso, pelo que este demonstra ou parece demonstrar" (ARISTÓTELES, 2012, p. 13). Hoje, conhecidas como éthos, páthos e lógos respectivamente, as provas retóricas estão entremeadas no discurso e influenciam de modo definitivo a maneira como se argumenta, pois, ao apresentar-se perante um auditório, o orador constrói uma imagem de si, reveste-se de prudência, virtude e benevolência para inspirar confiança, suscitar emoções e facilitar a adesão dos ouvintes a sua tese.

Considerando as três provas de persuasão fornecidas pelo discurso, elegemos como linha condutora de nossa proposta didática a construção etótica do personagem João Grilo perante seu auditório no Auto da Compadecida, porque o éthos é, segundo Aristóteles, um dos principais meios de persuasão, de forma que sua fluidez nos possibilita abarcar toda a dinâmica retórico-argumentativa presente no texto. Apesar de admitirmos a relevância do lógos na construção etótica do orador, cabe salientar que a concepção de éthos adotada nesse artigo extrapola a clássica vertente aristotélica, pois consideramos, para além do discursivo, também o pré-discursivo de Maingueneau (2006) e os ethé prévio e efetivo abordados por Meyer (2007).

Segundo Maingueneau o éthos constitui-se como uma noção fundamentalmente híbrida, sociodiscursiva, pois "mesmo que o destinatário nada saiba do éthos do locutor, o fato de ele estar ligado a um dado gênero do discurso ou a certo posicionamento ideológico induz expectativas no tocante ao éthos" (MAINGUENEAU, 2006, p. 269). A "voz" do locutor é indissociável das demais "imagens de si” construídas, dinamicamente, ao longo de sua história

\section{LINHA DÁGUA}


pelos destinatários; deste modo, o éthos visado não corresponde, necessariamente, ao produzido, pode haver discrepâncias a depender das perspectivas construídas pelo locutor ou destinatário. Contemplando tanto a dimensão discursiva, quanto a pré-discursiva de éthos, Maingueneau amplia, sob a perspectiva da análise do discurso, a concepção aristotélica inicial. Essa noção híbrida nos permite considerar também o éthos pré-discursivo de João Grilo na obra e avaliar seu impacto na construção discursiva desse orador pelo auditório; ademais, ao destacar o dinamismo presente nesse processo, Maingueneau nos leva a conceber o éthos de maneira multidimensional, considerando as representações prévias tanto do orador Grilo, quanto de seus auditórios, bem como a construção discursiva de cada uma das partes.

Meyer nos permitirá ampliar o arcabouço teórico-prático relevante à argumentação para considerar o éthos sob a perspectiva da problematicidade e do constante binômio projeção $\mathrm{x}$ efetivação presente na interação entre orador e auditório. Ao partir da concepção aristotélica inicial e questioná-la, Meyer (2007, p. 35) relaciona o éthos à figura do orador "como princípio e também como argumento de autoridade", destacando os atributos morais e intelectuais que o tornam capaz de responder aos questionamentos do auditório e garantir sua confiança. Nessa construção etótica, as imagens não correspondem forçosamente à realidade: tanto orador, quanto auditório forjam imagens de si; o éthos projetado não necessariamente equivale àquele construído pelo auditório e vice-versa, de modo que a defasagem entre os ethé é realidade frequente na interação entre as partes e deve ser considerada pelo orador ao proferir seu discurso. Essa realidade torna-se presente também na obra, uma vez que João Grilo orna-se, constantemente, das virtudes e dos valores que o auditório valoriza para construir-se discursivamente. Forjando por efetivo o éthos projetivo, Grilo adapta-se ao auditório para influenciar suas ações, persuadi-lo.

A partir do arcabouço teórico descrito, compreendemos que o éthos situa-se entre o orador e a audiência, é construído pré e discursivamente de maneira interacional, mútua. Antes mesmo de se dirigir ao auditório, o orador, a partir de sua historicidade, de seu status como ser no mundo, de seus posicionamentos e atitudes anteriores, tem um éthos pré-discursivo, ou prévio construído, e também o mesmo ocorre com o auditório. Esse éthos pode ser legitimado ou modificado conforme a imagem de si forjada no discurso pelo orador, nesse sentido o lógos tem fundamental importância. Por isso, a análise do discurso de João Grilo não pode ser desvinculada de sua construção etótica perante os ouvintes.

Nesse contexto, conhecer o auditório, ou mesmo conseguir presumi-lo a partir das ideias compartilhadas, dos lugares-comuns (tópoi), da doxa, torna-se essencial à construção etótica do orador. São Chaim Perelman e Lucie Olbrechts-Tyteca que retomam, em 1958, os estudos aristotélicos e atualizam-nos. A partir das concepções de auditório ${ }^{6}$ e persuasão, apresentam “o

6 Perelman e Olbrechts-Tyteca conservam de Aristóteles a ideia de auditório como fim do discurso e definem sob qual perspectiva tomarão as palavras "discurso", "orador" e "auditório": “[...] quando utilizarmos os termos "discurso", "orador" e "auditório", entenderemos com isso a argumentação, aquele que a apresenta e aqueles a quem ela se dirige, sem nos determos no fato de que se trata de uma apresentação pela palavra ou pela escrita (PERELMAN; OLBRECHTS-TYTECA, 2005, p. 7)". Vale ressaltar, entretanto, que apesar de esses termos

\section{LINHA D'ÁGUA}


estudo das técnicas discursivas que permitem provocar ou aumentar a adesão dos espíritos às teses que se lhes apresentam ao assentimento" (PERELMAN; OLBRECHTS-TYTECA, 2005[1958], p. 4). Divididos por processos de ligação e dissociação de noções, os argumentos são classificados com o objetivo de analisar sua estrutura considerando a interação constante entre os elementos que constituem a situação argumentativa, conforme o Quadro 1.

Quadro 1. Tipologia de argumentos perelmaniana

\begin{tabular}{|c|c|c|}
\hline \multirow{5}{*}{ Processos de ligação } & \multicolumn{2}{|l|}{ Argumentos Quase Lógicos } \\
\hline & \multirow{2}{*}{$\begin{array}{l}\text { Argumentos Baseados na } \\
\text { estrutura do real }\end{array}$} & Ligações de sucessão \\
\hline & & Ligações de coexistência \\
\hline & \multirow{2}{*}{$\begin{array}{l}\text { Ligações que fundamentam a } \\
\text { estrutura do real }\end{array}$} & Caso particular \\
\hline & & Raciocínio por analogia \\
\hline Processos de dissociação & \multicolumn{2}{|c|}{ Dissociação das noções } \\
\hline
\end{tabular}

Fonte: Capitani (2021, p. 87), elaborado a partir de Perelman e Olbrechts-Tyteca (2005[1958]).

Em termos de ensino, ao abordar a construção etótica de João Grilo na obra, é importante compreender aspectos analíticos tais quais descritos por Perelman e Olbrechts-Tyteca (2005).A capacidade de lidar com o ato de discussão perpassa a leitura atenta de um discurso argumentado, saber identificar e analisar criticamente um argumento por meio de sua estrutura, observando os mecanismos de orientação dos sentidos, a maneira de enquadrar o problemático e as estratégias utilizadas para favorecer determinados posicionamentos e contra-argumentar é primordial para ampliar as competências de leitura, reflexão e questionamento dos discentes ${ }^{7}$.

Autores contemporâneos como Christian Plantin, Michel Meyer, Rui Grácio repensam a atividade argumentativa em um quadro ampliado no qual o desacordo sobre determinada questão é fundamental para fazer emergir posicionamentos discursivos diversos. Nesse âmbito:

[...] a retórica é a negociação da diferença entre os indivíduos sobre uma questão dada... O que constitui a sua diferença, e mesmo o seu diferencial, é certamente múltiplo, mas uma coisa é certa: se não houvesse um problema, uma pergunta que os separasse, não haveria debate entre eles, nem mesmo discussão. A linguagem, o lógos, tem por vocação traduzir o que constitui um problema. [...] Sem questões, já dizia Aristóteles, não haveria duas escolhas contrárias, todos teriam o mesmo ponto de vista e não consultariam senão a si próprios para esclarecer as coisas. Dessa forma, a retórica é a análise dos questionamentos que são feitos na comunicação interpessoal e que a suscitam ou nela se encontram. (MEYER, 2007, p. 25-26)

serem tratados de modo semelhante neste artigo, não desconsideramos a perspectiva interacionista presente no intercâmbio de papéis entre orador e auditório e de seus respectivos turnos de palavras.

7 Embora o foco desse artigo não recaia diretamente sobre as técnicas argumentativas, não deixamos de reconhecer seu valor e importância. Caso haja interesse em abordá-las de modo mais extenso, recomendamos a leitura de nossa tese de doutorado (CAPITANI, 2021).

\section{LINHA DÁGUA}


Segundo esses teóricos, a argumentação é fundada na dúvida, na divergência de opiniões que pode levar à confrontação de discursos tanto sob o modo polêmico, quanto cooperativo de uma maneira interativa e dialogal. Tomando a argumentação a partir do ponto de vista interacionista-dialogal, Grácio explica que:

De acordo com esta concepção uma argumentação caracteriza-se por uma estrutura trilógica em que se podem destacar três pólos fundamentais: o proponente, o oponente e a questão ou terceiro. A noção de assunto em questão é essencial, tal como a divergência de discursos. Mais do que levar a ver o discurso do ponto de vista da influência sobre um auditório, esta concepção opta por considerar que uma argumentação se realiza de argumentador para argumentador. Não que dela seja descartada a noção de influência, mas esta é vista à luz da interacção e, mais especificamente, à luz da ideia de interdependência discursiva. A vantagem desta concepção é a de poder considerar o valor "argumento" no interior da interacção circunstanciada em que ele ocorre (GRÁCIO, 2010, p. 77).

Grácio (2013, p. 47) define, portanto, a argumentação como “[...] a disciplina crítica de leitura e interação entre as perspectivas inerentes à discursividade e cuja divergência os argumentadores tematizam em torno de um assunto em questão". Segundo o teórico, é uma "disciplina" porque exige a capacidade de focalização do assunto em questão; é "crítica" porque exige a construção de uma oposição discursiva; de "leitura e interação" porque é preciso ler o discurso do outro para interagir com ele; "entre perspectivas inerentes à discursividade" porque são elas que estão em causa nas argumentações; e "cuja divergência os argumentadores tematizam em torno de um assunto em questão" porque é a partir dele e da tematização que é possível interagir.

Nota-se que, do ponto de vista interacionista-dialogal, o que está em pauta é perceber a maneira como as perspectivas se desenham no modo de tematizar os assuntos, é ser capaz de ler esse contradiscurso que problematiza para interagir com ele. Por isso, Grácio toma como unidade metodológica de análise da argumentação a situação argumentativa em toda sua completude, tendo em vista quem são os argumentadores, como emergiu o assunto em questão, qual a problemática discutida, por quem é composto o auditório, qual a finalidade específica para argumentar, que argumentos são apresentados, como se articulam aos da parte oposta e de que maneira ocorreu o desfecho da problemática. Nesse sentido, apresentar uma proposta didática retórico-interacionista que possibilite ao docente, a partir da obra literária, criar situações argumentativas com o objetivo de ampliar, de modo articulado, as capacidades argumentativas dos alunos é fundamental no âmbito educacional, visto que o papel do educador, afirmava Freire (2007), é reforçar a capacidade crítica do educando e instigá-lo a polemizar.

[...] só uma competência argumentativa - que nos capacita para decompor os raciocínios, analisar a interação e o alcance dos discursos, ponderar a pertinência dos argumentos - nos permite posicionar crítica, esclarecida e activamente face seja a que discurso for. (GRÁCIO, 1998, p. 94) 


\section{Apresentação de uma proposta didática retórico- interacionista}

Ao propor uma discussão pautada na construção do éthos de João Grilo enquanto orador na obra Auto da Compadecida, os docentes dispõem-se a construir um espaço argumentativo marcado pela divergência de perspectivas. Esse processo de discussão e análise do problemático no situacional parece-nos produtivo para ampliar a capacidade de ouvir, dialogar, refletir, optar por um posicionamento e comprometer-se, assumindo uma atitude responsável e responsiva acerca do que é dito, competência argumentativa essencial para assegurar uma performance comunicativa apropriada às exigências práticas da vida do discente.

Partindo do pressuposto de que o docente seja também um argumentador, pois, na práxis em sala de aula, ele argumenta para promover aprendizagens, adotar uma metodologia tradicional cujo viés mecanicista, tecnicista e conteudista favoreça a construção de um sujeito passivo é contradizer a abordagem interacionista-dialogal presente nessa pesquisa. Considerando, pois, a argumentação a partir dessa dimensão interativa, a proposta didática foi construída com base em "questões motivadoras" a fim de gerar espaço para a discussão, coconstrução de conceitos e práticas argumentativas entre docentes e discentes. Tendo em vista que o termo "questão", segundo Grácio (2012), instala uma problemática e constrói, por meio da articulação de múltiplas perguntas e respostas, uma cadeia interrogativa que remete ao domínio das perspectivas e das possibilidades, optou-se por essa terminologia e respectiva postura metodológica para que, ao longo de toda a proposta didática, o conhecimento seja construído em um espaço democrático, de maneira dialogal, interacional e colaborativa por um educador/educando ${ }^{8}$ cuja conduta seja, de fato, democrática, tal qual descrita por Paulo Freire (2007).

Pressupõe-se, neste âmbito, um educador que tenha efetivamente disponibilidade para ouvir o discurso alheio e assumir essa posição dialogal em sua metodologia em sala de aula. Esse educador "deve motivar, isto é, desafiar quem escuta, no sentido de que, quem escuta diga, fale, responda." (FREIRE, 2007, p. 117). Para promover essa "responsividadade", esse ato de resposta dos sujeitos, essa tomada de posição responsável da qual já falava Bakhtin na obra Para uma filosofia do ato responsável (2010), é necessário, primeiramente, despertar a atenção dos discentes, conquistar sua simpatia, sensibilizá-los a respeito do que é apresentado, captar

8 Referimo-nos ao conceito de dodiscência explicado por Freire (2007, p. 23) do seguinte modo: "não há docência sem discência, as duas se explicam e seus sujeitos apesar das diferenças que os conotam, não se reduzem à condição de objeto, um do outro. Quem ensina aprende ao ensinar e quem aprende ensina ao aprender"

9 Segundo Bakhtin (2015) a comunicação discursiva é marcada pela alternância dos sujeitos do discurso e pela tomada de posição ativa a propósito do que é dito e compreendido. "Toda compreensão da fala viva, do enunciado vivo é de natureza ativamente responsiva; toda compreensão é prenhe de resposta, e nessa ou naquela forma a gera obrigatoriamente: o ouvinte se torna falante. A compreensão passiva do significado do discurso ouvido é apenas um momento abstrato da compreensão ativamente responsiva real e plena, que se atualiza na subsequente resposta em voz real alta" (BAKHTIN, 2015, p. 271).

\section{LINHA DÁGUA}


sua benevolência, agir sobre seu entendimento e vontade, convocando faculdades intelectivas e afetivas para ensinar (docere), emocionar (movere) e agradar (delectare).

Ao selecionar o repertório (inventio), elaborar o arranjo mais conveniente (dispositio), fazer escolhas no plano da expressão (elocutio) e colocar o discurso em prática por meio da actio e da memoria, é fundamental que o docente considere as predisposições dos discentes, conheça suas crenças, seus valores, a doxa sobre a qual se alicerça seu pensamento e adapte-se a ela para, enfim, tomar a palavra e ser ouvido. Nesse processo, a tríade retórica, éthos, páthos, lógos faz-se presente, pois ao instalar a problemática por meio de um discurso coerente, prudente e razoável (phrónesis), o docente mostra-se digno de fé, transmite uma imagem virtuosa (areté,) competente de si e mobiliza afetivamente os discentes, atuando sobre suas emoções ao revelar-se benevolente, simpático e solidário (eunóia).

Para despertar o interesse dos discentes sobre o tema a ser abordado, é importante também estar atento ao modo como os conteúdos curriculares são apresentados no discurso em sala de aula; se apartados de seus aspectos práticos e em desarticulação com a vida, a história e o contexto sócio-econômico-cultural dos discentes, é pouco provável que sejam valorizados e aprendidos. Há, portanto, de se estabelecer um vínculo mais estreito entre o conteúdo estudado e a experiência social dos alunos, sua cultura e saberes. Em vista disso, os elementos culturais nordestinos, tais como músicas folclóricas, folhetos de cordel, xilogravuras são aproveitados na proposta didática em questão para contextualizar a obra e levar os discentes a compreenderem o Sertão mundo de que falava Suassuna.

Com o propósito de promover também um ambiente alegre, acolhedor, propício, inclusive, a conquistar a simpatia dos alunos, captar sua benevolência e promover uma experiência de leitura multissensorial, propõe-se decorar a sala com folhetos de cordéis ${ }^{10} \mathrm{de}$ múltiplas temáticas e recepcioná-los ao som da música Presepada, do grupo instrumental SaGrama ${ }^{11}$, cujo trabalho versa sobre música pernambucana baseada nas manifestações populares.

Essa trilha sonora ${ }^{12}$, tema do filme a ser trabalhado posteriormente, gera a possibilidade de perscrutar os conhecimentos dos discentes. De maneira dinâmica, até mesmo teatral, dançante, o docente pode instigá-los a estabelecer relações entre a música, a região e a cultura nordestinas. Por meio do questionamento, incitando à discussão, é possível conhecer tanto as

10 Apesar de ter sido concebida pressupondo a utilização de folhetos de cordel, de sistemas de áudio e imagem em sala, a falta dessas ferramentas não impossibilita o desenvolvimento da proposta didática sugerida, pois o objetivo maior neste contexto é despertar a simpatia dos alunos pela obra, captar sua benevolência e atenção para que a experiência de leitura crítica, interativa não se torne enfadonha. Isso pode ser feito também via discurso, a partir das estratégias argumentativas empregadas pelo docente em sala; obviamente há de se ter um domínio mínimo de tais fundamentos para aplicá-los com precisão, todavia a leitura atenta dos capítulos $2^{\circ} \mathrm{e}$ $3^{\circ}$ de nossa tese de doutorado (CAPITANI, 2021) oferece subsídios para que o docente possa fazê-lo.

11 Pode-se acessar a música por meio do seguinte link: https://www.youtube.com/watch?v=y1MLp5s2Q_Q

12 Trilha sonora composta por Sérgio Campelo e Cláudio Moura para o filme de Guel Arraes adaptado da obra original de Ariano Suassuna.

\section{LINHA DÁGUA}


potencialidades, quanto as lacunas dos alunos, considerá-las e traçar estratégias para lidar com elas. Conceber o auditório presumido tão próximo quanto possível da realidade, conforme afirmavam Perelman e Olbrechts-Tyteca (2005), é a condição prévia não só para argumentar, mas também para ensinar. Preocupar-se com a heterogeneidade presente em sala de aula e conceber maneiras de abarcar a todos, prezando pela equidade, é uma demonstração de apreço pelo aprendizado dos alunos e pela educação vista como direito de todos.

Nesse contexto, convém desenvolver também uma associação entre literatura e música para trazer à luz a historicidade da literatura de cordel, do Romanceiro Popular Nordestino, cujas raízes remontam ao Trovadorismo Medieval e aos poetas líricos dos séculos XII e XIII. Esse nexo torna-se relevante porque uma das constantes que orientaram a vida e a obra de Suassuna foi a busca da poética popular como modelo de criação. A partir da música, das artes plásticas e da literatura, ele expressou a essência de uma cultura popular brasileira. Apresentar, portanto, esse elo torna-se condição para que os discentes compreendam a construção do Auto da Compadecida tanto do ponto de vista estrutural, estilístico, linguístico, quanto temático, dóxico.

No bojo dessas associações literomusicais, há espaço para explorar a experiência de leitura dos discentes e apresentar aos que desconhecem os folhetos de cordel sua importância no cenário sociolinguístico e na tradição literária, não só regional, mas universal, uma vez que a obra popular carrega também reminiscências de outras culturas. Essa discussão favorece, inclusive, o desenvolvimento de um trabalho interdisciplinar entre língua portuguesa e história, uma vez que é preciso abordar um pouco da formação cultural, política e socioeconômica do povo nordestino para que o aluno compreenda as raízes populares presentes na obra discutida.

Estabelecer uma intrínseca relação entre a literatura popular nordestina, representada pelos folhetos de cordel, e a obra Auto da Compadecida é também essencial para que os discentes compreendam a originalidade da peça. Escrita a partir de trechos dos seguintes folhetos $O$ dinheiro de Leandro Gomes de Barros, História do cavalo que defecava dinheiro, de Leonardo Mota, O castigo da Soberba de Anselmo Vieira de Sousa e A peleja da alma de Silvino Pirauá de Lima, a obra mantém a essência desses "causos", mas é redimensionada a partir da perspectiva do autor, que destaca os embates socioideológicos de diferentes segmentos sociais do sertão nordestino em meados do século XX, para tematizar, sobretudo, a situação daqueles que se encontram em posição inferior na ordem social.

Apresentar aos discentes esses folhetos base, sugerindo, inclusive sua leitura como um exercício pós-aula, pode oferecer fundamentos para discutir a obra, compartilhar conhecimentos e mostrar a eles que o aproveitamento dos folhetos pelo autor não caracteriza plágio, conforme insinuam alguns críticos. Essa discussão pode ser construída a partir do texto abaixo, escrito por Bráulio Tavares (2014), no qual o próprio Suassuna aborda esse assunto. Caso seja pertinente, pode-se aproveitar o ensejo para traçar um rápido debate a respeito do tema plágio e autoria, visto que atualmente esse é um dos grandes problemas enfrentados pelos docentes ao requisitar um texto escrito aos alunos.

\section{LINHA DÁGUA}


[...] certa vez um crítico teatral abordou Ariano Suassuna e o inquiriu a respeito de alguns episódios do Auto da Compadecida. Disse ele: "Como foi que o senhor teve aquela ideia do gato que defeca dinheiro?" Ariano respondeu: "Eu achei num folheto de cordel." O crítico: "E a história da bexiga de sangue e da musiquinha que ressuscita a pessoa?" Ariano: "Tirei de outro folheto." O outro: "E o cachorro que morre e deixa dinheiro para fazer o enterro?" Ariano: "Tirei de outro folheto, também." O sujeito impacientou-se e disse: "Agora danou-se mesmo! Então, o que foi que o senhor escreveu?" E Ariano: "Oxente! Escrevi foi a peça!" (TAVARES, 2014, p. 177)

Ao introduzir a obra é preciso que o docente seja capaz de agir retoricamente sobre os alunos a ponto de persuadi-los a lê-la. As estratégias discursivas de que falavam Aristóteles na Antiga Retórica e Chaim Perelman na Nova Retórica podem, inclusive, ser empregadas com essa finalidade. Aguçar a curiosidade dos alunos, propagandeando a obra a partir da apresentação de temáticas cotidianas, tais como a miséria, a exploração nas relações de trabalho, a corrupção na esfera religiosa, o preconceito racial, pode ser um meio para conquistar a adesão do grupo e gerar, consequentemente, uma identificação entre a obra e o leitor. Exibir o trailer ${ }^{13}$ do filme $O$ Auto da Compadecida, de Guel Arraes, destacando os elementos sócio culturais que constituem a obra, contribui para promover problematizações, ilustrar a discussão e granjear a atenção dos discentes, pois construído como ferramenta publicitária para o cinema, o trailer tem a finalidade de promover o produto e persuadir o público a assistir ao filme.

Após a exibição do trailer, recomenda-se que o docente abra uma discussão sobre os temas e personagens com o objetivo de avaliar como se deu a recepção da obra. Para promover, paulatinamente, a tematização do assunto a ser tratado é oportuno questionar qual a imagem (éthos) construída pelos alunos a respeito do personagem João Grilo, tomando por base as concepções trazidas pelo trailer e confrontando-as com a peça original ${ }^{14}$. Nesse processo o docente pode tanto selecionar os trechos da peça a serem apresentados, quanto dividir a turma em grupos e propor a busca pelos trechos em cada um dos atos. Apesar de demandar mais tempo à atividade, essa última opção poderia trazer aos alunos benefícios em termos de leitura e apropriação do contexto relativo à argumentação. Procederemos, entretanto, à apresentação dos trechos no Quadro 2 para elucidar esse processo de construção etótica do personagem:

13 O trailer está disponível no seguinte link: https:/www.youtube.com/watch?v=x7ISUk6Y35Q

14 A problematização construída gera ainda ensejo para discutir as diferenças entre a adaptação cinematográfica e a obra literária original, destacando a diferença entre os gêneros discursivos cinema e texto teatral. É conveniente, ressaltar que não se pode tomá-los como equivalentes. Em termos de roteiro, por exemplo, o filme O Auto da Compadecida é composto por uma miscelânea de obras que não estão presentes na peça original. Os personagens Cabo Setenta, Rosinha, originalmente Marieta, e Vicentão advêm da peça Torturas de um Coração; já o episódio da porca, caução do casamento entre Rosinha e Chicó, provém da peça $O$ Santo e a Porca, cujo tema principal é a avareza, característica presente em vários personagens do Auto da Compadecida, dentre eles o padeiro. Logo, assistir apenas ao filme pode levar à construção de uma perspectiva alheia à arte literária original.

\section{LINHA DÁGUA}


Quadro 2. Tematização do assunto em questão: construção etótica do personagem João Grilo ATO I

Bispo: Quem é João Grilo?

Padre: Um canalhinha amarelo que mora aqui e trabalha na padaria. (SUASSUNA, 2014, p.64)

Chicó: João, deixe de ser vingativo que você se desgraça! Qualquer dia você inda se mete numa embrulhada séria! (SUASSUNA, 2014, p. 30)

ATO II

Padeiro: Ladrão! Ladrão! Ingrato, eu nunca o despedi, apesar de todas as suas trapaças! (SUASSUNA, 2014, p. 87)

Severino: Chega então a vez de Sua Desgracência, o Senhor João Grilo, o amarelo mais amarelo que já tive a honra de matar. (SUASSUNA, 2014, p. 103)

Severino ao Cangaceiro: Aponte o rifle pra esse amarelo, que é desse povo que eu tenho medo! (SUASSUNA, 2014, p.104)

Chicó: João, meu filho, você é grande! Vamos embora! (SUASSUNA, 2014, p. 111-112)

Chicó: João, João! Morreu! Ai meu Deus, morreu pobre de João Grilo! Tão amarelo, tão safado e morrer assim! Que é que eu faço no mundo sem João? João! João! Não tem mais jeito, João Grilo morreu. Acabou-se o Grilo mais inteligente do mundo. (SUASSUNA, 2014, p. 114)

\section{ATO III}

Encourado: [...] Mas vamos aos fatos. Que vergonha! Todos tremendo! Tão corajosos antes, tão covardes agora! O senhor bispo, tão cheio de dignidade, o padre, o valente Severino...E você, o Grilo que enganava todo o mundo, tremendo como qualquer safado! (SUASSUNA, 2014, p. 122)

Manuel: [...] Que direito tem você de repreender João porque falou comigo com certa intimidade? João foi um pobre em vida e provou sua sinceridade exibindo seu pensamento...

Manuel: Muito obrigada, João, mas agora é sua vez. Você é cheio de preconceitos de raça. (SUASSUNA, 2014, p. 128)

Manuel: Sei que você é astuto, mas não pode negar o fato de que foi acusado. (SUASSUNA, 2014, p. 139)

Compadecida: João foi pobre como nós, meu filho. Teve de suportar as maiores dificuldades, numa terra seca e pobre como a nossa. (SUASSUNA, 2014, p. 157)

Chicó: Quando eu penso que pobre de João não tem nem direito a um enterro em latim! Coitado, está mais abandonado do que o cachorro do padeiro. Pobre de João! (SUASSUNA, 2014, p. 164)

Fonte: Autoria própria (2021). Trechos retirados de Suassuna, A. Auto da compadecida (2014).

Com o propósito de desenvolver nos discentes a capacidade de dialogar e interagir, o docente pode solicitar que fundamentem os juízos acerca das imagens (ethé) de João Grilo a partir da caracterização das situações argumentativas apresentadas nos trechos acima. Desse modo, gera-se ensejo para explorar os elementos constitutivos do discurso argumentativo e os efeitos gerados nos ouvintes/argumentadores, considerando o poder da linguagem enquanto instrumento de persuasão e ação sobre outrem. Isso requer, tanto do docente quanto dos

\section{LINHA DÁGUA}


discentes, atenção ao contexto em que a argumentação emergiu, isto é, qual a problemática em questão, quem são os argumentadores e o auditório, que posição social ocupam, quais os posicionamentos em voga, quais as estratégias discursivas utilizadas para a construção de seu discurso, qual a finalidade específica para a argumentação, como ocorreu o desfecho.

Para desencadear essa percepção nos alunos, o exercício de leitura precisa ultrapassar a superficialidade textual, as atividades de decodificação e cópia, pois essas raramente levam à reflexão crítica. Para promover a participação ativa e reflexiva desses leitores e penetrar a obra de maneira mais aprofundada, o docente pode partir da problematização e da formulação de hipótese ${ }^{15}$ para guiar a atividade de leitura em direção aos elementos constitutivos do discurso argumentativo, sem perder de vista as circunstâncias em que ele ocorre, bem como seu caráter interacional.

Ao questionar, criar hipóteses e observar como se constroem as múltiplas perspectivas retratadas no texto, os discentes podem, enfim, posicionar-se. Nesse processo, suas competências argumentativas são ampliadas, pois levados a interagir com os seus pares nessa discussão, apreendem a dimensão cooperativa do diálogo marcada pela disposição para ouvir, desejo de comunicar e respeito às perspectivas contrárias. Atentos à situação argumentativa, podem identificar o assunto em questão, analisar os modos de argumentar, considerando o perspectivismo inerente aos posicionamentos construídos, para selecionar o que importa trazer ao discurso.

Á medida que avança nos conceitos acerca da argumentação de modo dialogal, o docente sensibiliza os alunos sobre os poderes da linguagem enquanto meio de interação social, aprofunda o conhecimento de estratégias argumentativas em contexto interacional; e incrementa, gradativamente, as habilidades performativas inerentes ao argumentar, descritas por Grácio (2016).

Ao longo desse processo, é esperado que ele mantenha a atenção do seu auditório/aluno na questão discutida. Portanto, o modo de desenhar os assuntos e enquadrar o problemático não pode ser desprezado ao longo das aulas. Com o propósito de causar estranhamento, gerar curiosidade e manter o auditório focado na questão, o professor pode partir das justificativas apresentadas pelos alunos acerca do éthos de João Grilo para, posteriormente, intrigá-los por meio da dúvida ${ }^{16}$ da seguinte maneira: tendo em vista que o conjunto de características atribuídas a esse personagem tem, de modo geral, cunho difamatório ${ }^{17}$, conforme apontado, por

15 A formulação de hipótese é uma das estratégias de leitura elencadas por Solé (1998).

16 Wayne Brockriede (2009), ao situar a argumentação na dimensão do problemático, apresenta seis características fundamentais desse ato comunicativo, uma delas sendo a regulação da incerteza. Regular a incerteza dos discentes, conforme sugerido acima, intensifica a necessidade de argumentar e pode suscitar maior discussão em sala de aula.

17 Dada a extensão do artigo, não procederemos à análise detalhada do éthos de João Grilo em cada situação argumentativa da obra. Para obtê-la, indicamos a leitura de nossa tese de doutorado, em que constam, inclusive, quadros explicativos dessa proposta didática (CAPITANI, 2021).

\section{LINHA DÁGUA}


que, ao final da peça, ele torna-se porta-voz do grupo em um momento tão decisivo quanto o julgamento? Vocês, na condição de réus, confiariam seus destinos a um "amarelo safado"? Cabe apresentar aos alunos o trecho abaixo (Vide Quadro 3) como justificativa para tal questão:

Quadro 3. Regulação da incerteza do auditório/aluno: João Grilo como porta-voz do grupo (defasagem etótica)

João Grilo: [...] Quer ver eu dar um jeito nisso, Padre João?

Padre: Quero, João!

João Grilo: E você, Senhor Bispo?

Bispo: Eu também, João.

João Grilo: Padeiro:

Padeiro: Veja o que pode fazer, João.

João Grilo: Severino? Mulher e cabra?

Mulher: Nós também. Nossa esperança é você.

João Grilo: Tudo precisando de João Grilo! Pois vou dar um jeito.

Encourado: É isso que eu quero ver.

Manuel: Com quem vai se pegar, João? Com algum santo? (SUASSUNA, 2014, p. 143-144)

Fonte: Autoria própria (2021). Trechos retirados de Suassuna, A. Auto da compadecida (2014).

Ao apresentar a defasagem entre os ethé construídos ao longo da obra e aquele reconstruído ao final, o docente gera ensejo para discutir a construção etótica do personagem e enfatizar que ela não é instantânea e estática, se constitui ao longo do processo, com base nas escolhas competentes, deliberadas e apropriadas do orador/argumentador no discurso, é passível de transformação, sendo dinâmica, portanto.

Pode-se observar no texto que João Grilo é percebido como competente, razoável, equânime, sincero e solidário, quando se dispõe a resolver o assunto em questão na posição de porta-voz do grupo. Ao solicitar autorização para representar cada acusado, sua autoridade se redefine dinamicamente neste espaço conflituoso: ele deixa de ser visto como um "amarelo", "canalha", "trapaceiro" para simbolizar a esperança do auditório que em vida lhe condenou, conforme ressalta a mulher do padeiro: "nossa esperança é você".

É somente nesse cenário de desalento e angústia que o auditório reconhece o éthos de pertencimento de Grilo e o valoriza. Isso ocorre porque ele demonstra competência argumentativa, se mostra discursivamente capaz de desenhar assuntos em questão, enquadrar o problemático, posicionar-se e traçar estratégias argumentativas tendo em vista a heterogeneidade do auditório, as diferentes perspectivas e o jogo de concessões e refutações que perpassam a dinâmica interação argumentativa. Assim, ele corresponde aos interesses, às conveniências do auditório, prova ser digno de fé e obtém credibilidade perante aqueles que o censuravam. Encarna, enfim, o indivíduo simbólico que melhor representa o grupo no julgamento.

\section{LINHA DÁGUA}


Mostrar aos discentes como ocorre esse processo de reconstrução etótica ao longo da obra, com base no contexto no qual emergem os assuntos em questão, como se constroem as posições dos personagens a partir dos interesses em voga, de que modo são perspectivadas as problemáticas, quais as finalidades da argumentação, as estratégias argumentativas implementadas, os efeitos gerados e o desfecho da situação argumentativa permite compreender o éthos como realidade problemática de todo e qualquer discurso, afinal ele se produz no lógos, na competência argumentativa manifesta pelo orador e na sua capacidade de sensibilizar o ouvinte, tocar suas emoções, despertar-lhe o páthos.

A fim de estabelecer uma relação intrínseca entre o objeto de conhecimento e as experiências sociais dos discentes, propõe-se ainda que o docente amplifique a discussão e traga a questão para o contexto em sala de aula perguntando aos discentes qual seria o colega escolhido para interceder por eles, caso estivessem em uma posição tal qual os réus do Auto da Compadecida, e por quê. Ao fazer tal associação, ele aborda a construção etótica dos alunos em meio ao grupo e gera ensejo para discuti-la, permitindo notar em que proporção o éthos é importante na interação argumentativa entre orador e auditório, de modo prático, contextualizado, leva-os, enfim, a construir sentidos para o que aprendem.

Além de desencadear mecanismos cognitivo-discursivos essenciais à aprendizagem e ao exercício do pensamento reflexivo, o ensino de argumentação voltado à perspectiva retóricointeracionista, tal qual exposta, implementa, a partir do texto literário, competências argumentativas essenciais para assegurar uma performance comunicativa apropriada ao confronto de perspectivas inerente à experiência humana.

Com o objetivo de responder tanto às demandas da prática docente acerca dos processos que envolvem o ensino de argumentação, quanto às necessidades impostas pela sociedade contemporânea em relação ao desenvolvimento dessas competências pelos discentes, a proposta didática apresentada voltou-se a discutir os caminhos que se pode percorrer a fim de preparar os alunos para lidar com o "ato de discussão" sem prescindir do fato de que "uma didática da argumentação deve preocupar-se em formar argumentadores que efetivamente participam em argumentações "(GRÁCIO, 2012, p. 401-402).

\section{Considerações finais}

Ler o mundo sob a ótica da argumentação implica a capacidade de colocar a si e aos outros em questão por meio do discurso. Segundo Grácio (2010), a questão faz refletir, liberta as eventuais respostas para o domínio do possível, das perspectivas, nos faz habitar a suspensão da dúvida e do problemático, convoca a articulação de múltiplas perguntas, requer, enfim, uma postura crítica e aberta à investigação a partir da interação argumentativa entre as partes. Nessa dinâmica problematizadora, a alteridade tem um lugar fundador, pois os discursos são reexaminados, as perspectivas reconstruídas e as diferenças negociadas à luz da interação colaborativa entre o "eu" e o "tu".

\section{LINHA DÁGUA}


Nesse cenário, a educação escolar consiste em um lócus adequado ao exercício da argumentação, pois, em interação com o colega, o aluno é frequentemente confrontado com posicionamentos contrários sobre os quais precisa argumentar. Nesse espaço, a disciplina de Língua Portuguesa exerce fundamental importância, visto que uma de suas finalidades é justamente possibilitar aos discentes ampliar a capacidade de utilizar a língua para agir discursivamente em diferentes situações de comunicação.

Proceder ao exercício da reflexão durante o processo de leitura, análise e interpretação do texto em sala de aula, como sugerido na proposta didática apresentada, possibilita desencadear nos discentes tanto a capacidade de refletir sobre a situação argumentativa apresentada no texto, analisando na conjuntura de oposição discursiva a construção da imagem de si quanto a capacidade de refletir para as situações argumentativas, isto é, considerando a dimensão prática do argumentar em que se torna fundamental observar as peculiaridades das situações para adaptar-se discursivamente.

Abordar a obra a partir de uma concepção humanizadora de literatura, tal qual descrita por Candido (2011), pautada no exercício da reflexão, favorece ainda a ampliação das capacidades e competência argumentativa dos discentes, porque organizada a partir da palavra, a produção literária permite observar a maneira pela qual a mensagem é construída no texto para despertar nos discentes um olhar atento aos poderes da linguagem enquanto meio de interação social em diversas situações. A literatura possibilita penetrar nos problemas da vida e, por meio da ficção, gera questionamentos, incita o leitor a posicionar-se. Nesse processo, cria espaço para desenvolver um trabalho didático voltado a incrementar nos discentes as habilidades performativas inerentes ao argumentar. Voltada à instrução, à aquisição do saber a partir da ficção, a literatura permite-nos aprofundar nos discentes o conhecimento de processos, dinâmicas, meios e estratégias argumentativas manifestas nas diversas situações de argumentação presentes no texto literário.

A proposta didática retórico-interacionista apresentada neste artigo permitiu discutir a construção étotica do personagem João Grilo, ancorado nos indícios do lógos. Ao final, foi possível constatar que o éthos desse personagem não é uno, nem fixo, é múltiplo, ou seja, ele não é o "canalhinha amarelo", conforme define o padre, ou "o Grilo mais inteligente do mundo", conforme afirma Chicó; pode ser ambos ou nenhum, a depender do auditório com o qual argumenta e das circunstâncias em que isso ocorre. Os ethé são definidos e redefinidos dinâmica e interacionalmente no espaço conflituoso das situações argumentativas constituídas ao longo da peça. Por isso examinar o processo de construção etótica implica ter em vista a interação constante entre os elementos que constituem o discurso.

Desenvolver essa perspectiva ampla de análise do texto literário a partir de uma abordagem didática problematizadora, tal qual apresentada na proposta retórico-interacionista, tendo em vista situações de aprendizagem em que são articulados o exame analítico e a performance interacional dos discentes, pode levá-los a mobilizar saberes curriculares e relacioná-los as experiências sociais para agir de modo argumentativo em situações cotidianas.

\section{LINHA DÁGUA}


À luz das teorias da argumentação, pudemos compor "um itinerário" que permite oferecer ao docente essa perspectiva ampla de leitura e abordagem da obra no ensino básico, apontamos caminhos para que ele possa produzir e adaptar saberes de cunho retóricointeracionista a sua realidade escolar, a partir da avaliação das capacidades de argumentar dos alunos. Aliamos, enfim, o conhecimento acadêmico acerca das teorias da argumentação à experiência docente da pesquisadora para oferecer aos colegas meios de tornar mais nítidas as relações entre argumentação e literatura em sala de aula, visando a ampliação da competência argumentativa dos discentes. Estabelecemos um diálogo entre a universidade e o ensino básico, tendo em vista os diversos desafios pelos quais atravessa o ensino de Língua Portuguesa, sem descuidar, portanto, do lugar e da responsabilidade do pesquisador junto à comunidade.

Assim como Chicó inventa para fugir da realidade, nós criamos porque não podemos estar em conformidade com ela; se a pesquisa aplicar-se-á a todos os contextos de ensino, deixemos, portanto, Chicó responder: "Não sei, só sei que foi assim" (SUASSUNA, 2014, p. 22).

\section{Referências}

ARISTÓTELES. Retórica. São Paulo: WMF Martins Fontes, 2012.

AZEVEDO, I. C. M. de. Desenvolvimento de competências e capacidades de linguagem por meio da escrita de textos de opinião. In: EID\&A - Revista Eletrônica de Estudos Integrados em Discurso e Argumentação, Ilhéus, n. 4, p. 35-47, jun. 2013.

BAKHTIN, M (Volochínov). Marxismo e filosofia da linguagem: problemas fundamentais do método sociológico na ciência da linguagem. $4^{\mathrm{a}}$ ed. São Paulo: Hucitec, 1988.

BAKHTIN, M. Para uma filosofia do ato responsável. São Carlos: Pedro \& João Editores, 2010.

BAKHTIN, M. Estética da Criação Verbal. $6^{\mathrm{a}}$ ed. São Paulo: WMF Martins Fontes, 2015.

BAKHTIN, M. Notas sobre literatura, cultura e ciências humanas. São Paulo: Editora 34, 2017.

BARTHES, R. A aula. São Paulo: Cultrix, 1977.

BRASIL. Ministério da Educação e Cultura. Base Nacional Comum Curricular. Ensino Fundamental e Médio. Brasília, DF, 2017.

BRASIL. Ministério da Educação. Lei de Diretrizes e Bases da Educação Nacional, no 9394 de 20 de dezembro de 1996. Brasília, DF: MEC, 1996.

BROCKRIEDE, W. Onde está a argumentação? [1975] Tradução de Ricardo Grácio e Rui Alexandre Grácio. In: Revista Comunicação e Sociedade. Coimbra, v. 16, 2009, p. 13-17.

CANDIDO, A. O direito à literatura. In: CANDIDO, A. Vários Escritos. $5^{\mathrm{a} e d . ~ R i o ~ d e ~ J a n e i r o: ~}$ Ouro sobre Azul, 2011, p. 171-193.

\section{LINHA D'́GUA}


CAPITANI, C. A. Articulações entre o ensino-aprendizagem de Argumentação e de Literatura: caminhos Retórico-Interacionistas a partir do Auto da Compadecida. 2021, $427 \mathrm{f}$. Tese de Doutorado - Faculdade de Filosofia, Letras e Ciências Humanas, Universidade de São Paulo, São Paulo, 2021. DOI: https://doi.org/10.11606/T.8.2021.tde-13082021-210307.

COMPAGNON, A. Literatura para quê? Belo Horizonte: Editora UFMG, 2009.

COSSON, R. Letramento literário: teoria e prática. São Paulo: Contexto, 2006.

DALVI, M. A; FALEIROS-JOVER, R; REZENDE, N. L. de (Orgs.). Leitura de literatura na escola. São Paulo: Parábola, 2013.

FERREIRA, L. A. Retórica e determinação dos sentidos: as perguntas da escola e as respostas da vida. In: MOSCA, L. do L. S. (Org.) Retórica e Argumentação em práticas sociais discursivas. Coimbra, Grácio Editor, 2016, p. 141-158.

FREIRE, P. Pedagogia da Autonomia: saberes necessários à prática educativa. 36 a ed. São Paulo: Paz e Terra, 2007.

GRÁCIO, R. A. Consequências da Retórica: para uma valorização do múltiplo e do controverso. Coimbra: Pé de Página Editores, 1998.

GRÁCIO, R. A. A interacção argumentativa. Coimbra: Grácio Editor, 2010.

GRÁCIO, R. A. Teorias da Argumentação. Coimbra: Grácio Editor, 2012.

GRÁCIO, R. A. Perspectivismo e argumentação. Coimbra: Grácio Editor: 2013.

GRÁCIO, R. A. A argumentação na interação. Coimbra: Grácio Editor, 2016.

LAJOLO, M. P. Usos e abusos da literatura na escola: Bilac e a literatura escolar na República Velha. Rio de Janeiro: Globo, 1982.

LEAHY-DIOS, C. Educação literária como metáfora social: desvios e rumos. Niterói: EdUff, 2000.

LEITÃO, S; DAMIANOVIC, M. C. (Orgs). Argumentação na escola: o conhecimento em construção. Campinas: Pontes Editores, 2011.

MAINGUENEAU, D. Discurso literário. São Paulo: Contexto, 2006.

MEYER, M. A retórica. São Paulo: Ática, 2007.

PERELMAN, C; OLBRECHTS-TYTECA, L. Tratado da argumentação: a nova retórica. $2^{\mathrm{a}}$ ed. São Paulo: Martins Fontes, 2005[1958].

PLANTIN, C. A argumentação: histórias, teorias, perspectivas. São Paulo: Parábola Editorial, 2008.

SOLÉ, I. Estratégias de leitura. $6^{\text {a }}$ ed. Porto Alegre: Artmed, 1998.

SUASSUNA, A. Auto da Compadecida. 36 a ed. Rio de Janeiro: Nova Fronteira, 2014.

TAVARES, B. Tradição popular e recriação no Auto da Compadecida. In: SUASSUNA, A. Auto da Compadecida. $36^{\mathrm{a}}$ ed. Rio de Janeiro: Nova Fronteira, 2014.

ZILBERMAN, R. A leitura e o ensino da literatura. Curitiba: IBPEX, 2012.

Recebido: 30/04/2021.

Aprovado: 02/08/2021. 